RESEARCH ARTICLE

\title{
HOW DOES ISLAMIC LAW AND NATIONAL LAW LOOK AT THE RELINQUISHING OF CHILDREN'S RESPONSIBILITIES TO THEIR PARENTS?
}

\author{
Rokhmat Sucipto \\ Sekolah Tinggi Agama Islam Walisembilan, Semarang, Indonesia \\ $\triangle$ rokhmatsucipto2@gmail.com
}

\section{CITED AS}

Sucipto, R. (2020). How Does Islamic Law and National Law Look at the Relinquishing of Children's Responsibilities to Their Parents?. Journal of Law and Legal Reform, 1(4), 617-630. https://doi.org/10.15294/jllr.vli4.39888

\begin{abstract}
The obligation of children to provide for their parents and the growing reality in Indonesia today, many children leave their parents but give up their livelihood obligations. The question arises how the practice of releasing children from their parents at the Wredha Harapan Ibu (PWHI) Nursing Home in Bringin Ngaliyan Semarang is a perspective of Islamic law and positive law. Article 46 Paragraph (2) Marriage Law Number 1 of 1974. The research author uses descriptive analysis method that is analyzing information about the real situation now. The study uses field research with interview and documentation methods as well as taking various supporting literature to be used as a reference in the preparation of this study. This research approach is normative. The results of the author's research: First, first entrusted until now the parents have never filled their children. Secondly, first of all, they are left with routine maintenance once fulfilled, but the habit does not last long. Third, the first deposited until now has never given a living, but still gives a living only rarely given. In Islamic law the release of parents' living is not in line with the teachings and recommendations of the Islamic religion which are stated in the AlQuran and Al-Hadith as well as the agreement of the ulama as well as contrary to the positive law in force in Indonesia as stated in the Law Article 46 Paragraph (2) Law Number 1 of 1974 concerning marriage.
\end{abstract}

Keywords: Parents Rights; Islamic Law; National Law; Children Responsibilities 


\section{TABLE OF CONTENTS}

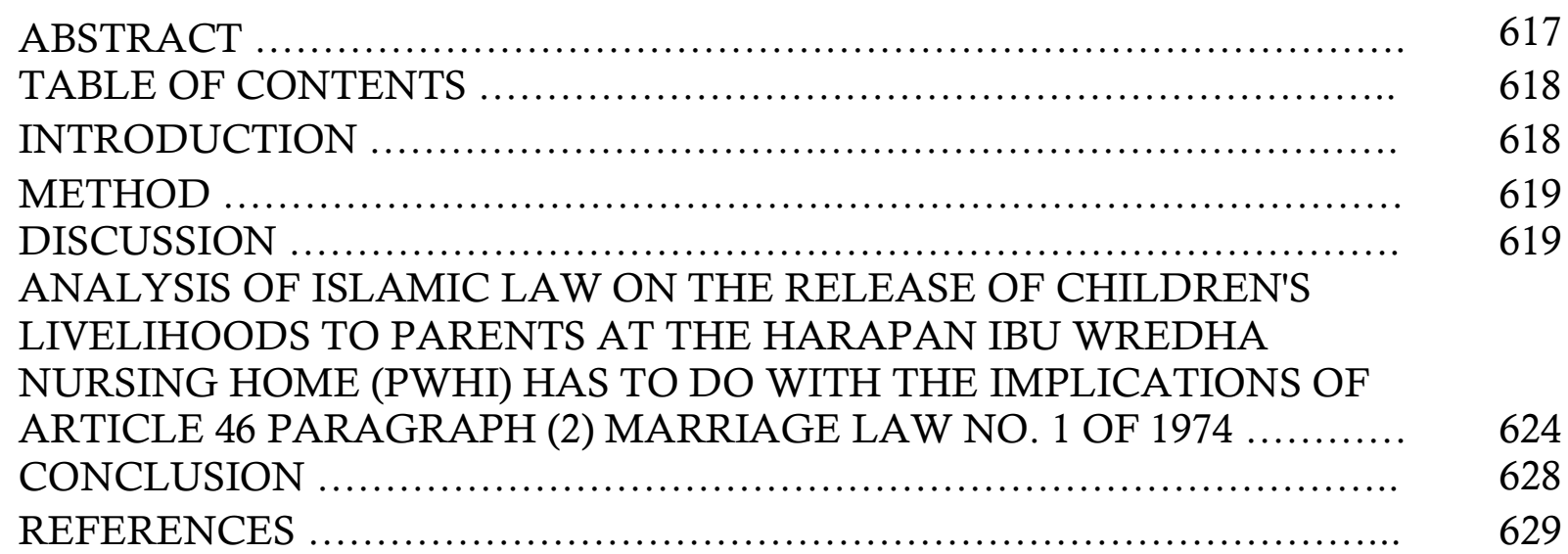

\section{INTRODUCTION}

Children and parents have a close relationship and cannot be separated in the family environment. One of the obligations that must be fulfilled is fulfilling or providing a living, so that there is a very close reciprocal relationship between a child and parents as well as in terms of living (Al-Baihaqi, 789).

In the book of Islamic law, it is said, a person who has a spacious life means that he has the obligation to maintain or provide for his father's parents who are lacking, as well as the mother of his parents from both parties. (Asef. A.A. Fyzee, 1960). The obligation to provide for both parents as Allah SWT commands to his servants contained in the Qur'an such as surah Al-Baqarah verse 215, Al-Israa 'verse 83, Surat An-Nisaa' verse 36, Surah Luqman verses 14 and 15, Surat Al-Ankabut verse 8 , Surat al-Halab verse 2, Surat ath-Thalaq verse 7 in which explains the obligation to provide for parents. Parents are also included in some so-called relatives, but in Islam the term is separated, especially in terms of living. Obligation of children in providing a living is the right of parents to receive a living. The child's obligation to provide for his parents is confirmed in the word of Allah Al-Baqarah [2]: 215) (Ministry of Religion of the Republic of Indonesia, 2007). 


\section{METHOD}

In this research the method used is descriptive analysis method, while the type of field research is research that relies on observations in field data collection such as the Interview Method (Interview), Documentation. Because this concerns the issue of interrelation between the law and other social institutions, this research is a nondoctrinal social study, or it can also be referred to as sociological legal research (social legal research). Because this research is a sociological law research, it is emphasized on the value of benefit and the value of justice. The data sources are primary and secondary data.

\section{DISCUSSION}

\section{Understanding Making a Living}

Etymologically, living comes from Arabic namely from the syllable anfaqa - yunfiqu infāqan (قفاقفنا - قفني - قفنا). In the Arabic-Indonesian dictionary, etymologically the word living is defined as the right to spend and/or spend (Yunus, 1989). There are also those that specifically limit the definition of living to only three main aspects, food (math'am), clothing (malbas), and boards (maskan), even narrower than that is only on math'am (Erfani, 2011; Subaidi, 2014).

\section{Basic Law of Livelihood}

In terms of the obligation of children to provide for their parents has been affirmed based on the proposition of the Qur'an, as-Sunnah and Ijma (agreement of the scholars) as well as positive law of Indonesia.

a) The basis of the Qur'an

yas-aluunaka maadzaa yunfiquuna qul maa anfaqtum min khayrin falilwaalidayni waal-aqrabiina waalyataamaa waalmasaakiini waibni alssabiili wamaa taf'aluu min khayrinfa-inna allaaha bihi 'aliimun

Meaning: "They ask about what they spend. Answer: "Whatever wealth you give should be given to ladies and gentlemen, relatives, orphans, poor people and people who are on their way." and whatever good you make, then surely Allah knows. "(Q.S al-Baqarah: 215) (Erfani, 2011). 
b) The basis of Hadith

The issue of income for both parents is also mentioned in the hadith of the Prophet Muhammad which is narrated by An-Nasa'i:

$$
\text { وابدأ بمن تعول أمك وأباك وأختك وأخاك أدناك أدناك }
$$

"Begin (give a living) to those who are your dependents, your mother, your father, your sister, your brother, and so on." (HR. An-Nasa'i 1/350, Ibnu Hibban 810).

c) The basis of Ijma

From the proposition ijma' (consensus of the scholars) above, quoted by ibn alMundzir states that scholars agree, it is obligatory for the child to provide for both parents who are poor and have no job (Ibn Qudamah Al-Maqdisi, 1432 H).

d) Positive Law

1) Marriage Law No. 1 of 1974 Article 46, which reads:

1. Children should respect their parents and obey their good wishes.

2. When a child is an adult, he or she must keep his or her parents, and family in a straight line if they need help.

2) Presidential Instruction No. 119911991 Compilation of Islamic Law (KHI) in Indonesia related to living obligations to parents as well as repayment of parental debt to others. In the compilation of Islamic Law at article 175 it is explained that when a parent dies and has debt then the child as heir has an obligation to settle his debts including medical expenses, treatment and more.

3) Article 321 of the Indonesian Civil Code: "The children are obligated to support their parents and blood relatives in the ascending line, in the event that they become destitute. (Bw.311, 323, 329, 1282, 1296, 1429-3; Rv.749-3; Civ.205)

\section{Some Limitations and Development of Case}

This research underlines some of the definitions and limitations related to cases of neglect by children in Indonesia. Some of the things underlined by the Author are:

1) There is a family relationship (Abidin \& Aminuddin, 1999).

2) The members of the household concerned need to make a living.

3) Relatives who demand their living are not able/unable to work on their own (Abidin \& Aminuddin, 1999).

4) The person burdened with the obligation of living is capable or rich, except in the matter of the maintenance of the mother being compulsory to the child, and the maintenance of the child obligated to the father. 
5) The breadwinner and the breadwinner are religious, except in the matter of the father's maintenance of his son and of his parents' children.

Thus, regardless of the religion adopted by the parents, the capable child must provide for the parents, regardless whether or not the parent is the authority (Basyir, 2004). Then the obligation to provide for their parents, regardless of some conditions, are:

1) Children in the comfort of wealth are to have enough food to eat at that time.

2) Parents who have no assets. If the parents have the property, the child is not obligated to provide for the living even if the parents are in pain (Zuhri \& Solomon, 1978).

In this case Ahmad bin Hanbali said that when a child is in want or unemployment, his livelihood falls (Sabiq, 1986). In the same way, when it comes to benefiting their property, they should put their parents first, because they have been educating and caring for them from childhood to adulthood (Al-Maraghi, 1984).

Furthermore, psychiatrists have determined that the family relationship that makes compulsory living is that there is a close family in need. However, they have differing opinions on who exactly the immediate family is. Here are the 4 (four) opinions of jurists:

1) Imam Malik argues that the bread must be given by the father to the child, and then the child to the Father and the mother and is limited only there.

2) This is a farce that is the narrowest determinant of the family relationships that make this living. And the priest reacted to the word of Allah Almighty QS al-Isra': 23 (Ministry of Religion, 2007).

3) Imam Shafi'i held that the maintenance should be given to all families with vertical and lower ties, without limiting it to certain members.

4) The Hanafi held that the obligation to provide for the living was to all members of the family of the stranger, so that one should provide for all the families of the poor with him. Imam Hanafi quotes the Word of Allah SWT Q.S ar-Romans: 3738

5) Imam Ahmad ibn Hanbal was of the opinion that the maintenance should be given to all the surviving relatives, in case one of them died. So the neighborhood is expanding, including the whole family, strangers and non-strangers. Ahmad ibn Hanbal quotes the Word of Allah Almighty QS al-Baqarah: 233

According to Ibn Taimiyah, a rich child must provide for his father, mother, and younger siblings. If the child does not carry out the obligation, it means he has rebelled against his two parents and has broken off kinship. Giving a living to both parents is an obligation, the obligation is not a form of voluntary giving or giving, but a 
virtue (Syahatah, 1998). Thus, the livelihood obligations apply to children when both parents are no longer strong enough to try and do not have wealth (Basjid, 1976). Because basically the child and his property are still owned by parents. Abdullah bin Amr reported that one of his companions came to the Prophet and asked about his possessions but he had poor parents. He then asked if he was obliged to provide for his parents? The Prophet answered:

"Indeed, you and your property belong to your parents. And your children are part of your good income, then eat from your children's income" (HR. Tirmidzhi).

In this case the obligation to provide for the parents by the child is indeed something that is mandatory, but there are exceptions include:

1) Although children are obliged to provide for their parents, but if parents do not want to because it is very rich or because of other things, then the legal obligation is lost.

2) If the child is really unable or not strong enough to try, then the law must be null and void (Hasyim, 1990).

The study revealed that there are some facts that happened at Wredha Harapan Ibu (PWHI) Bringin Ngaliyan Semarang, some from the beginning left their parents until now never fulfilling all their needs, both material or immaterial needs, especially regarding material living which results in neglect of parents. by child. Regarding material needs such as clothing, food and shelter, for immaterial needs such as giving attention and affection, respect, pray, obey and avoid everything that hurts him. It is also never given to children by their parents, so that children openly give up their livelihood obligations and ignore their rights and responsibilities as a person. The occurrence of release of livelihood since the beginning entrusts until now on this problem cannot be separated from the problem in the body of the child's family, all caused by:

1) Busyness of the child so that they cannot take care of their parents at home.

2) Disharmony / always in conflict with parents and there is a misunderstanding between children and parents because of the love that must be divided.

3) Because parents do not want to trouble the family in caring for them.

4) Because of the physical and psychological condition of parents.

From this cause, the child or family who relinquishes their livelihood obligations until they leave their parents in the Ngaliyan Harapan Ibu (PWHI) Nursing Home Semarang turned out to be neglected with conditions that have no living costs and are unable to find a source of livelihood, so that their daily needs rely 
solely on the twelve sorry for the orphanage. Whereas there is also the existence of parents who, when entrusted at the orphanage by their children, are related to their obligation to provide a living to meet all the needs of parents while living in the orphanage, apparently routinely given every month and their livelihoods are often met. This habit does not last long only lasts at the beginning of day care and only runs about two months. So that after the increasing presence of parents in the orphanage, the income that should be received every month for their daily needs turns out that from time to time there is no longer providing child support for their parents.

While the problems related to the release of parents 'living by children in the Wredha Harapan Ibu (PWHI) Bringin Ngaliyan Semarang home apparently there is still also the release of the parents' living, when they first entrusted their parents up to now they have never been given a living, even though they still provide a living. but only modest and rarely given. Responsibilities and obligations as a child to support his parents are still very rarely given, it is almost not given at all but when giving his income is inadequate or just enough. Seeing so much the needs of parents in the orphanage, material livelihood that should be received is almost never given only enough for the needs of a few days, although still given but not how much given. For the needs of immaterial living alone is not given at all from the beginning of care until now has never been given.

From a number of different parental backgrounds, it turns out that it is owned by parents who still have biological children and families, where the biological children have enough income and have their own place of residence that the child should be obliged to finance all their needs and it turns out that the parents are only abandoned or abandoned left to stay at the orphanage, even though parents previously objected to being entrusted and to find out the condition of the parents at the orphanage how it is often said that the caregivers first contacted their children to notify their condition. When tracing back the case of parents who were entrusted at the Wredha Harapan Ibu (PWHI) Bringin Ngaliyan Semarang, it turned out that all the necessities of life of parents both material or immaterial have not been fulfilled their living rights. 


\section{ANALYSIS OF ISLAMIC LAW ON THE RELEASE OF CHILDREN'S LIVELIHOODS TO PARENTS AT THE HARAPAN IBU WREDHA NURSING HOME (PWHI) HAS TO DO WITH THE IMPLICATIONS OF ARTICLE 46 PARAGRAPH (2) MARRIAGE LAW NO. I OF 1974}

As the author has explained in the previous discussion, there is a release of parents 'living by the child that occurs at the Panti Wredha Harapan Ibu (PWHI) Bringin Ngaliyan Semarang, so that from the discussion above there have been many problems relating to the release of parents' living by the child the in PWHI. Various problems of parents who are entrusted in the orphanage are those from the time when they were entrusted until now their children relinquished their parents' livelihood obligations, and some at the beginning of day care provide for their daily needs until after now there is no visible gift from their children, until there was a person who was entrusted until now until he was not given his living, although he still only gave but was not able to meet all his needs. Basically, the obligation of children to provide for their parents has been established in Islamic law and positive law in Indonesia.

The obligation of the child to support the parents in the family has been affirmed based on general instructions, namely the word of God in the Al-Baqarah verse 215, which talks about the obligation of the child to provide for parents (Department of Religion, 2007). And confirmed again in the word of God Q.S al-Isra, 17: 26. The verse confirms the relationship between children and parents is a relationship that is very close and inseparable. The obligation to provide for parents is also mentioned in the hadith of the Prophet Muhammad which is narrated by AnNasa'i:

"Begin (give a living) to those who are your dependents, your mother, your father, your sister, your brother, and so on." (HR. An-Nasa'i 1/350, Ibn Hibban 810, and altered by al-Albani in Irwa 'al -Gholil 3/322).

Of all the scholars of the four schools have agreed, that children have the obligation to provide for their biological parents if they are no longer able to work, do not have income to meet their needs (Ibn Qudamah Al-Maqdisi, $1432 \mathrm{H}$ ). The scholars of the school of thought differed regarding who are the people who are entitled and obliged to provide for their living and what are the conditions. 
a. Imam Hanafi argues, the main requirement for the necessity of living towards relatives is the existence of a relationship that causes marriage forbidden between them, the obligation includes father to up and children to the bottom (Mughiyah, 1999).

b. Imam Maliki said that living is only mandatory for both parents and children who are direct descendants and does not include others.

c. Imam Hanbali said, fathers and so on must oblige and be entitled to a living. Likewise, for children who continue to go down, with the condition that the person who provides the living has the right to inherit the person who is given a living (Mughiyah, 1999).

d. Imam Shafi'i said that children are obliged to provide for their parents and continue to be above both male and female, just as parents provide for their children to continue downward. This obligation does not cover people who are outside the nasab line, such as uncle, both from the path of the mother and father's path (Mughiyah, 1999).

The scholars of madzhab determined that basically they could not leave their parents in a nursing home, unless they were in a very forced condition and based on their desires, permits and willingness, and were not forced to be caused by their parents' bad behavior (Yamami, 2005). As long as there are regulations that allow the child to leave his parents in an orphanage for reasons that are acceptable with the terms and conditions that apply according to customs, culture or beliefs, all of which are fine as long as they do not violate the applicable rules. Basically the obligations of children to their parents must be fulfilled directly by their children, but for reasons that are justified by syara 'then the child may carry out obligations to his parents indirectly by representing or entrusting to someone or a social institution such as a nursing home. The existence of elderly parents has been explained in Law No. 4 of 1965 Chapter 1 Article 1. According to Law No. 13 of 1998 concerning Elderly Welfare in Chapter I article 1 paragraph 4 stated that: "Elderly potential is the elderly who are powerless to make a living so that their lives depend on the help of others". So, based on the Act clearly states that the existence of parents is need of assistance in the form of a living to meet the needs of life and prosperity. According to Law No. 13 of 1998 concerning Elderly Welfare in Chapter I article 1 paragraph 4 stated that: "Elderly potential is the elderly who are powerless to make a living so that their lives depend on the help of others".

As a child, he is obliged to pay respect to his parents and obey all his commands both in looking after and caring for him and providing all the necessities needed when the parents are entrusted with PWHI, the statement is explained in the Marriage Law No. 1 of 1974 Article 46 paragraph (1). Furthermore, related to the 
release of the parents' living at the Panti Wredha Harapan Ibu (PWHI) Ngaliyan Semarang a few children who abandoned their parents without any provision of living to live their lives, as well as the lack of extra and special attention from the child to parents both material or immaterial living. . If reviewed with positive law / legislation in force in Indonesia, namely Article 46 paragraph (2) Marriage Law Number 1 of 1974 concerning Marriage which states that: "If the child is an adult, he is required to maintain according to his ability, parents and family in a straight line up, if they need their help". While in the Child Protection Act article 19 letter (a) also states that: "Every child has an obligation to respect parents, guardians and teachers" (Child Protection Act). Some previous researches also emphasized that there are relationship between moral obligations and responsibilities in the case of parents and children in Home for Elderly, like PWHI (Smeeton, 2011; Ardiansyah, Nggeboe, \& Harris, 2017; Latifiani, Arifin, \& Ramadhanty, 2018; Faridah \& Afiyani, 2019; Dewi \& Arifin, 2019; Muntamah, Latifiani, \& Arifin, 2019).

Therefore every child has moral obligations and responsibilities towards parents who have raised and nurtured him from childhood to adulthood (Shihab, 2005). Welfare itself, especially for parents, is when the needs are fulfilled from the child or from family and relatives. In the Government Regulation of the Republic of Indonesia No. 43 of 2004 concerning the Implementation of Efforts to Improve Social Welfare of Elderly Article l, which explains the purpose of welfare. The prohibition of someone who has grown up not to give up the obligation to provide for the sake of the survival of people in his old age, the prohibition has been regulated in Article 9 paragraph (1) of Law Number 23 Year 2004 concerning the Elimination of Domestic Violence which says that:

"Everyone is prohibited from neglecting people within the scope of his household, even though according to the law in force for him or because of an agreement or agreement he is obliged to give life, care, or care to that persoz" (Djubaidah, 2010).

As for the sanctions related to someone who relinquished his livelihood obligations resulting in neglect of others within the scope of the household as referred to in Article 9 paragraph (1) of the PKDRT Act (Substitute for Domestic Violence) based on Article 49 letter (a) of the PKDRT Law is a prison sentence a maximum of 3 (three) years or a maximum fine of Rp. 15,000,000.- (fifteen million rupiah) (Djubaidah, 2010). Then in the compilation of Islamic Law (KHI) explains about the obligation to make a living to parents only related to the payment of parental debt to others. Furthermore, in Article 175 of the Compilation of Islamic Law (KHI) it is 
explained that if a parent dies and has a debt, the child as an heir has an obligation, namely to settle his debts in the form of medication, care and others. So the responsibility of the heirs (children) for the debts of parents is limited to the amount or value of parental inheritance. Therefore, if a parent's debt exceeds his inheritance, then a child is not required to pay the parent's debt to someone else. So Islamic law lays down the prohibition of giving up livelihood by the child to the parent, because giving income to the parent is the child's obligation and responsibility as a form of reciprocity of the child to the parent who has been raised from childhood to adulthood. So that Islamic law provides provisions for parents who receive a living in a state of poverty and are unable to make a living because they are old or sickly as well as children who are mature and have good fortune (able) to provide for both parents and are not allowed by the state and religion. For the authors of the matter, it is very contradictory to Article 46 paragraph (2) of the Marriage Law Number 1 of 1974 and is not in line with the aims and objectives of the Act.

With the proven release of living at the orphanage, it shows that the mandate of the Act is not realized and does not provide full awareness of the importance of the child's role in the obligation and responsibility to provide for when parents need help. Therefore, the Marriage Law in article 46 paragraph (2), according to the author, does not provide a confirmation of the obligation to provide for parents. For the sake of legal certainty there needs to be strict sanctions if the child intentionally and blatantly releases his obligations and responsibilities for his livelihood to parents. So the existence of this Law can not guarantee the fulfillment of their living rights, so far the condition of parents is still suffering and losses due to the release of parents' living by the child in the orphanage. From this the lack of serious attention to the obligations and responsibilities of children in meeting their parents' living needs as stipulated in Article 46 paragraph (2) of Marriage Law No. 1 of 1974 concerning marriage. The lack of effectiveness of the Act has a significant impact on children's understanding of their obligations to provide for their parents in the form of material or immaterial living. In this case, the author states that there are still many acts that violate or violate the law as well as the neglect of the Law by children regarding their obligation to provide for living when parents are in the institution, as is the case in the Bringin Ngaliyan Nursing Home (PWHI) Bringin Ngaliyan Semarang. The law is not aware of children and is not applied among families who entrust their parents to be changed so that their duties and obligations to provide for living are not implemented and apparently do not guarantee the fulfillment of the living rights of parents and also the lack of legal certainty in efforts to realize the lives of parents who happy and prosperous, and not 
being able to become a legal umbrella to demand when their living rights from the children are not fulfilled.

The author concludes that the problem of releasing a living in the Panti Wredha Harapan Ibu (PWHI) Bringin Ngaliyan Semarang is very contradictory or against Islamic law and is not in line with the aims and objectives of the Act, namely Article 46 Paragraph (2) Marriage Law Number 1 of 1974 which regulates the obligation of children to support their parents. Therefore, legal firmness and strict sanctions are needed so that the rights of parents are protected because the problem of living is a basic necessity in life and is an obligation from the child to the parent. So that positive law in Indonesia must be firm, clear and detailed related to sanctions for the release of parents' livelihoods and the enforcement of laws based on justice.

\section{CONCLUSION}

This study highlighted and concluded that, in principle, children are obliged to provide for their parents and are responsible for looking after and caring for them instead of running away from responsibility by putting them in a nursing home, apparently there are still children who run and release their livelihood obligations to parents. As for the practice of releasing a living that occurs in nursing homes, there are some point emphasized, that first there are those who during the period of care from the first time they are deposited in the orphanage for many years until now have never once fulfilled the needs of parents for their children. Second, there is also the existence of parents who when first deposited at the orphanage by their children in connection with the obligation to earn a living were routinely given every month and their livelihoods were often met. But the habit does not last long only lasts at the beginning of day care and runs for only a few months, in fact from time to time there is no longer providing child support for their parents until now. Third, there are those who first left their parents until now they have never been given a living, but when they still provide only a modest income and still very rarely given. Forth, according to Islamic law towards children who entrust their parents at the Wredha Harapan Ibu (PWHI) Bringin Ngaliyan Semarang until the release of a living which results in neglect of parents in the orphanage, it turns out the child does not carry out responsibilities and obligations to provide for living and does not meet all the needs of people old. This is clearly not in line with the teachings and recommendations of the Islamic religion which are stated in the Al-Quran and $\mathrm{Al}$-Hadith as well as the ulama's agreement. The 
case also contradicts the positive law in force in Indonesia as stated in Article 46 Paragraph (2) of Law Number l of 1974 concerning marriage.

\section{REFERENCES}

A.A. Fyzee, A. (1960). Pokok-Pokok Hukum Islam-I. Jakarta: Tinta Mas. Abdullah, H. (1993). Kunci Fiqh Islam. Semarang: Asy-Syifa'i.

Al-Baihaqi, A.B. (n.d.) Sunan Al-Kubra. Beirut: Dar Al-Kutub Ilmiah

Al Barry, Z. A. (1997). Hukum Anak-anak Dalam Islam. Jakarta: Bulan Bintang.

Al-Fauzan, S. (2006). Fiqih Sehari-hari. Depok: Gema Insani.

Al-Jurjawi, A.A. (1992). Terjemah Falsafah dan Hikmah Hukum Islam. Semarang: CV. AsySyifa'i.

Al-Maraghi, A.M. (1984). Terjemahan Tafsir Al-Maraghi. Semarang: CV. Toha Putra.

Al-Maqdisi, I. Q. (1432 H). Al-Mughni. Beirut: Dar 'Alam al-Kutub.

Aminuddin, S. A. (1999). Fiqh Munakahat 1. Bandung: Pustaka Setia.

Ardiansyah, A., Nggeboe, F., \& Hariss, A. (2017). Kajian Yuridis Penelantaran Anak

Oleh Orang Tua Menurut Persfektif Hukum Indonesia. Legalitas: Jurnal Hukum, 7(1), 98-144.

Arikunto, S. (2002). Prosedur Penelitian Suatu Pendekatan Praktek. Jakarta: PT Rineka Cipta.

Ayyub, S. H. (2008). Fiqih Keluarga. Jakarta: Pustaka Al-Kautsar.

Basyir, A. A. (2004). Hukum Perkawinan Islam. Yogyakarta: UII Press.

Basjid, S. (1976). Fiqh Islam. Jakarta: Attahiriyah.

Brata, S.S. (1995). Metodologi Penelitian. Jakarta: PT Raja Grafindo Persada.

Dewi, M. B. K., \& Arifin, R. (2019). Emancipation and Legal Justice; Portrait of Women's Legal Protection in Indonesia. Jurnal Cita Hukum, 7(1), 101-114.

Department of National Education. (2011). Kamus Besar Bahasa Indonesia. Jakarta: Gramedia Pustaka Utama.

Diibu Bhigha, M. (1986). Fiqh Menurut Mazhab Syafi'i, Moh Rifa'i \& Baghawi Mas'udi (trans). Semarang: Cahaya Indah.

Djubaidah, N. (2010). Pencatatan Perkawinan e Perkawinan Tidak Dicatat Menurut Hukum Tertulis di Indonesia dan Hukum Islam. Jakarta: Sinar Grafika.

Erfani, E. (2011). Implikasi Nafkah dalam Konstruksi Hukum Keluarga, Paper of Candidates for Judges at the Tangerang Religious Court.

Faridah, S., \& Afiyani, L. (2019). Isu Pekerja Anak Dan Hubungan Dengan Hak Asasi Manusia. Lex Scientia Law Review, 3(2), 163-176.

Hadari, M., \& Nawawi, H. (1992). Instrumen Penelitian Bidang Sosial. Yogyakarta: Gajah Mada University Press. 
Hadits (350) HR. An-Nasa'i 1/350, Ibnu Hibban 810, and validated by al-Albani on Irwa' al-Gholil 3/322.

Hadits (3528) HR. Abu Daud, No. 3528; An-Nasai on Al-Kubra, 4: 4. Al-Hafizh Abu Thahir.

Hasyim, U. (1990). Anak Shaleh Surabaya: PT. Bina Ilmu.

Husein, M. (2001). Fiqh Perempuan, Yogyakarta: LKiS.

Ihroni, T. O. (ed). (2001). Bunga Rampai Sosiologi Keluarga. Jakarta: Yayasan Obor Indonesia.

Kunto, S. A. (1991). Prosedur Penelitian Suatu Pendekatan Praktek. Jakarta: Rineke Cipta.

Latifiani, D., Arifin, R., \& Ramadhanty, K. A. (2018). Hak Anak Angkat dalam Mendapatkan Warisan Ditinjau Dari Hukum Waris Indonesia. Normative Jurnal Ilmiah Hukum, 6(2 November), 66-78.

Mahalli, A. M. (2008). Menikahlah, Engkau Menjadi Kaya, Yogyakarta: Mitra Pustaka.

Moloeng, L. J. (2001). Metodologi Penelitian Kualitatif. Bandung: Remaja Rosda Karya.

Muntamah, A. L., Latifiani, D., \& Arifin, R. (2019). Pernikahan dini di Indonesia: Faktor dan peran pemerintah (Perspektif penegakan dan perlindungan hukum bagi anak). Widya Yuridika, 2(1), 1-12.

Mughiyah, M. J. (1999). Fiqh Lima Mazhab, Masykur A.B, Afif Muhammad, Idrus AlKaff (trans). Jakarta: Lentera.

Sabiq, S. (1986). Fiqh Sunnah. Bandung: Al-Ma'arif.

Salomo, M., \& Zuhri, R. M. (1978). Terjemahan Kifayatul Akhyar. Semarang: CV Toha Putra.

Shihab, U. (2005). Kontekstualitas Al-Qur'an Kajian Tematik Atas Ayat-ayat Hukum dalam Al- Qur'an. Jakarta: Penamadani.

Subaidi, S. (2014). Konsep Nafkah Menurut Hukum Perkawinan Islam. ISTI'DAL: Jurnal Studi Hukum Islam, 1(2), 157-169.

Sunggono, B. (1997). Metodologi Penelitian Hukum. Jakarta: PT Raja Grafindo Persada.

Sugiyono, S. (2009). Metode Penelitian Kuantitatif Kualitatif dan RひD. Bandung: Alfabeta.

Subekti, T. (2006). Kitab Undang-undang Hukum Perdata. Jakarta: PT. Pradnya Paramita.

Syahatah, H. (1998). Ekonomi Rumah Tangga Muslim. Jakarta: Gema Insani Press.

Smeeton, J., \& Boxall, K. (2011). Birth parents' perceptions of professional practice in child care and adoption proceedings: implications for practice. Child \& Family Social Work, 16(4), 444-453.

Yamami, Z. (2005). "Tinjauan Hukum Islam terhadap Kewajiban Alimentasi antara Orang Tua dengan Anak dan Konsekuensi Yuridisnya dalam Hukum Positif", Thesis, IAIN Sunan Kalijaga Yogyakarta.

Yunus, M. (1989). Kamus Arab Indonesia, Jakarta: Hidakarya Agung.

Zuhaili, W. (2008). Fiqih Imam Syafi'i. Jakarta: PT. Niaga Swadaya.

Zuhri, M. R., \& Salomo, S. (1978). Terjemahan Kifayatul Akhyar. Semarang: CV Toha Putra. 